\title{
Spilocaea oleagina in Olive Groves of Southern Spain: Survival, Inoculum Production, and Dispersal
}

\author{
J. R. Viruega, J. Moral, L. F. Roca, N. Navarro, and A. Trapero, Departamento de Agronomía, ETSIAM, Universidad de Córdoba, \\ Campus de Rabanales, 14071-Córdoba, Spain
}

\begin{abstract}
Viruega, J. R., Moral, J., Roca, L. F., Navarro, N., and Trapero, A. 2013. Spilocaea oleagina in olive groves of southern Spain: Survival, inoculum production, and dispersal. Plant Dis. 97:1549-1556.

Olive scab caused by the mitosporic fungus Spilocaea oleagina is the most important foliar disease of olive. Limited information is available on pathogen survival and disease epidemiology; however, this information is essential for development of new control strategies. Pathogen survival and inoculum production on infected olive leaves and conidial dispersal were evaluated during 4 years in an olive orchard of the susceptible 'Picual' in southern Spain. Infected leaves in the tree canopy were important for pathogen survival and conidia production. The number of conidia per square centimeter of scab lesion and their viability varied greatly throughout the seasons and between years; conidial density in lesions was highest (about 1 to $5 \times 10^{5}$ conidia $\mathrm{cm}^{-2}$ ) from November to February in favorable years. Conidial density declined

sharply in other periods of the year (becoming zero in summer) or in less favorable years. The pathogen did not form new conidia in scab lesions, although some pseudothecia-like structures and chlamydospores were detected on fallen leaves. Under humid conditions, the pathogen could not be detected on fallen leaves after 3 months because the leaves were colonized by saprophytic fungi. The dispersal of conidia as a function of distance from infected leaves in the tree canopy was well described by an exponential model which, together with the lack of conidia in a Burkard spore trap, showed that conidia were mainly rain-splash dispersed. Some trapped conidia were attached to olive leaf trichomes, suggesting that detached trichomes might enhance wind dispersal of conidia.
\end{abstract}

The fungus Spilocaea oleagina (syn. Cycloconium oleagineum) is the causal agent of olive (Olea europaea) scab, which is the most important leaf disease of this crop worldwide $(15,25,30,41,47)$. The disease is also called peacock spot because the pathogen produces circular, muddy green to almost black lesions with a chlorotic halo on the adaxial surface of the leaf $(1,15)$. The lesions change from a typical black scab during the winter or spring to a whitish scab during the summer, when the cuticle is separated from epidermal cells on infected leaves $(15,43)$. Lesions can also occur on leaf petioles, fruit, and fruit peduncles, although these tissues are not considered a significant source of inoculum $(1,15,41$, $44,45)$. Most infected leaves and fruit fall to the ground. Olive oil obtained from fallen fruit is of poor quality because various saprophytic fungi colonize the fruit and change the acidity and organoleptic characteristics of the oil (1). Olive scab is mainly controlled by a combination of sanitation and cultural measures, and by applications of copper-based fungicides; correct timing of fungicides is essential for effective control $(34,35,41,42)$.

Decisions about the need for pesticide applications in an integrated pest management program are generally based on knowledge of local (in-field) inoculum levels, which are determined by scouting, modeling, and field studies $(4,5)$. Overall, there is no evidence that $S$. oleagina produces sexual spores (ascospores); therefore, epidemics depend on the numbers of asexual spores (conidia) that are available $(15,42)$. However, the seasonal and yearly variation in conidial production is poorly understood.

Because Mediterranean climate is characterized by very long, dry and hot summers and mild to cool, wet winters, summers are

Corresponding author: A. Trapero, E-mail: trapero@uco.es

Current address of J. Moral: Instituto de Agricultura Sostenible (IAS), Consejo Superior de Investigaciones Científicas (CSIC), Apartado 4084, 14080-Córdoba, Spain.

Accepted for publication 6 May 2013.

http://dx.doi.org/10.1094/PDIS-12-12-1206-RE

(C) 2013 The American Phytopathological Society unfavorable for the aerial fungi of olive in this region. Several authors have determined that $S$. oleagina oversummers as mycelium in infected leaves that remain in the tree canopy $(15,16,41)$. In autumn, mycelia resume growth from the latent infections caused during the last spring or from old lesions, and new conidia are produced, which are dispersed by rain splash and run-off $(1,15,25,36,41)$. According to other authors, however, the most important inoculum sources are infected leaves that have fallen to the soil surface $(3,17,20)$. Moreover, Miller (25) indicated that the presence of other saprophytic fungi on olive leaves affects conidial production by $S$. oleagina. The epidemiological roles of fallen leaves and of saprophytic fungi on olive scab are unknown in Spain.

Because the mature olive leaves have ontogenic resistance to infection by $S$. oleagina, the main infection periods occur during the leaf growth $(31,44)$. In the northern hemisphere, the period for olive leaf growth lasts from March to mid-July; a second and less important flush may occur between September and mid-October, which coincides with the early autumn rains or irrigation applications (9). Weather conditions and the presence of developing leaves during early spring are usually adequate for leaf infection in olivegrowing areas in southern Spain $(31,36,44)$; therefore, leaf infection depends on inoculum (conidia) available.

Knowledge of dispersal distance and factors affecting the spread of conidia is essential for management of olive scab and other diseases involving conidia. For a fungal disease spread by airborne spores, the amount of diseased plant tissue typically decreases rapidly with increasing distance from a focus (source) of inoculum, because of the rapid decrease in the aerial spore concentration and deposition on plants with increasing distance from a source of inoculum $(4,5,14)$. The dispersal distance and its response to weather conditions have not been reported for olive scab as it has been for the ascosporic phase of similar pathogens, such as Venturia inaequalis and $V$. pirina $(4,18,23,39)$.

A better understanding of seasonal patterns of the production and dispersal of the $S$. oleagina conidia could improve management decisions in general and the timing of fungicide applications in particular. Consequently, the main objective of this study was to increase our understanding of olive scab epidemiology by monitor- 
ing conidial production on infected aerial and fallen leaves and conidial dispersal distance under field conditions. According to results of the present and previous studies $(31,44)$, the main risk period occurs during early spring due to the presence of conidia of the pathogen, favorable weather conditions (temperatures from 15 to $20^{\circ} \mathrm{C}$ and wetness duration $>24 \mathrm{~h}$ ), and the presence of developing leaves. Preliminary results of this work have been reported (45).

\section{Materials and Methods}

Olive orchard. The experimental orchard was located in a flat, uniform, 1.2-ha field at the Institute for Research and Formation in Agriculture and Fishery, Alameda del Obispo, Córdoba $\left(37.5^{\circ} \mathrm{N}\right.$, $4.8^{\circ} \mathrm{W}$, altitude $\left.110 \mathrm{~m}\right)$, Andalusia region, southern Spain. The orchard has a Typic Xerofluvent soil with a sandy-loam texture. The climate is Mediterranean, with most rainfall (95\%) occurring from October to May. The trees in the orchard were drip irrigated. The experimental orchard was managed according to the principles of commercial olive production in Andalusia (9). Copper-based fungicides (copper sulfate, $\mathrm{Cu}$ at $3.5 \mathrm{~kg} / \mathrm{ha}$ ) were applied during the spring and autumn to limit fungal foliar and fruit diseases (41).

Survival on aerial or fallen infected leaves. To study the inoculum dynamic and induce development of pseudothecia, we collected a total of 600 fallen olive leaves with scab lesions from different orchards of the Córdoba, Jaén, and Málaga provinces of Andalusia during September to October. After mixing the leaves, 500 leaves were placed in 10 nylon-mesh bags ( 18 by $18 \mathrm{~cm}$ with 2-mm openings, 50 leaves per bag) that were placed on the soil surface under the canopies of five trees ( 2 bags per tree). Inside the bags, the leaves were placed with the adaxial side up to prevent contact of scab lesions with the soil surface.

To induce the development of sexual stage of S. oleagina, as established for a similar pathogen such as $V$. inaequalis (23), we incubated the remaining 100 leaves in five moist chambers ( 22 by 16 by $10 \mathrm{~cm}, 20$ leaves per chamber) between two layers of moistened filter paper at $10 \pm 2{ }^{\circ} \mathrm{C}$ in the dark. One nylon bag or moist chamber was collected weekly, and each leaf was carefully examined at $\times 100$ magnification with a compound microscope (Nikon Eclipse 80i; Nikon Corp.) to detect fungal structures, including potential pseudothecia of $S$. oleagina. Moreover, three discs $(5 \mathrm{~mm}$ in diameter) per leaf were mounted on glass slides and stained with acid fuchsin in lactophenol $\left(50 \mathrm{mg} \mathrm{liter}^{-1}\right)$. The entire disc was scanned at $\times 400$ magnification, and conidia were identified and counted. Additionally, 100 leaves (these leaves are hereafter referred to as aerial leaves) showing typical whitish spots that appear after summer (43) were collected from the canopy of the trees during September. The leaves were incubated in four moist chambers in dark growth chambers with alternating temperatures of 20

Table 1. Fungal genera isolated from Spilocaea oleagina-infected olive leaves in the tree canopy or on the soil surface of a 'Picual' olive orchard in the Andalusia region of southern Spain

\begin{tabular}{lccc}
\hline \multirow{2}{*}{ Genus } & \multicolumn{3}{c}{ Olive leaves colonized by each fungal genus $(\%)^{\mathbf{a}}$} \\
\cline { 2 - 4 } & Tree canopy & Soil surface & Total \\
\hline Phoma & 51.3 & $14.3^{*}$ & 45.4 \\
Alternaria & 12.0 & 21.4 & 13.6 \\
Rhizopus & 4.0 & $28.5^{*}$ & 7.9 \\
Cladosporium & 5.4 & $14.3^{*}$ & 6.8 \\
Ascochyta & 6.7 & $0^{*}$ & 5.7 \\
Aureobasidium & 6.7 & $0^{*}$ & 5.7 \\
Coniothyrium & 5.4 & $0^{*}$ & 4.5 \\
Fusarium & 5.4 & $0^{*}$ & 4.5 \\
Mucor & 0 & $14.3^{*}$ & 2.2 \\
Diplodia & 1.3 & 0 & 1.1 \\
Trichoderma & 0 & $7.1^{*}$ & 1.1 \\
Ulocladium & 1.3 & 0 & 1.1 \\
\hline
\end{tabular}

a Values are means of four repetitions conducted in November 1995, August and October 1996, and January 1997, with 100 leaves per repetition. Within each row, an asterisk indicates a significant difference $(P<$ 0.05 ) between leaves in the tree canopy versus leaves on the soil surface (according to the Fisher's exact test). and $12^{\circ} \mathrm{C}$ and a 14-h photoperiod, which are optimal conditions for $S$. oleagina sporulation (44). Leaves in the moist chamber were collected weekly, and each leaf was carefully examined as described above to detect $S$. oleagina pseudothecia or spores. The study of fallen and aerial leaves was carried out in 1995 and again in 1997.

To confirm the observations made on fallen leaves in the experimental orchard, a survey was conducted in the main olive-growing areas of Andalusia. Fallen olive leaves with scab lesions that had overwintered on the soil surface under the tree canopy were collected during February 1996 and 1998. Each year, 50 samples (20 fallen leaves per sample) were examined microscopically for the presence of conidia or pseudothecia of S. oleagina.

Conidial density and viability on aerial or fallen infected leaves. During four consecutive seasons (from November 1993 to September 1997), 70 completely developed leaves showing $S$. oleagina symptoms were arbitrarily removed from each of three trees every 2 weeks in the experimental orchard; leaves were collected from different trees on each sampling date. Forty leaves from each of the three olive trees were individually attached to a glass microscope slide ( 26 by $76 \mathrm{~mm}$ ) using double-sided adhesive tape (Scotch, clear transparent; 3M Company) on each sample date. The conidia on the leaves were stained with acid fuchsin in lactophenol, and the number of conidia in $0.16 \mathrm{~mm}^{2}$ (area of a visual field of $\times 40$ microscope objective) of lesion per leaf was determined at $\times 400$ magnification (11). Because 120 leaves were examined on each date, the number of conidia in a total lesion area of $19.2 \mathrm{~mm}^{2}$ was determined.

To study conidial viability, we used the remaining 30 leaves from each of the three olive trees to obtain a suspension of $10^{5}$ conidia $\mathrm{ml}^{-1}$. One $5-\mu \mathrm{l}$ drop of the conidial suspension was placed on each of two microscope coverslips (20 by $20 \mathrm{~mm})$ to test germination of conidia. The coverslips (suspension side up) were placed in petri dishes containing water agar (WA). The dishes, which served as humidity chambers, were kept in the dark at $15^{\circ} \mathrm{C}$ for $48 \mathrm{~h}$. Conidial germination was stopped by staining with acid fuchsin in lactophenol, and the percentage of conidia that germinated was determined by observing 50 conidia selected arbitrarily on each coverslip. A conidium was considered germinated if the germ tube length was at least one-half the length of the longitudinal axis of the conidium. For each date, the trial was performed four times.

A similar study was conducted using infected leaves placed on the soil surface under the canopies of several trees in the experimental orchard. The leaves had previously been placed in 10 nylon-mesh bags ( 18 by $18 \mathrm{~cm}$ with 2 -mm openings, 50 leaves per bag), and the bags were placed on the soil surface. Conidial density and viability of conidia on 50 leaves (one bag) were assessed every 2 weeks for approximately 3 months. The study was carried out during March 1995, November 1996, and April 1997.

Fungal diversity on aerial and fallen infected leaves. We studied the biodiversity of fungi on olive leaves by examination of mycelium or spores on 100 leaves from the tree canopy and 100 fallen leaves. The aerial and fallen leaves were separately placed in 0.25 -liter Erlenmeyer flasks with $150 \mathrm{ml}$ of sterile water with Tween 20 at $1.5 \mathrm{ml} /$ liter. To remove mycelium or spores, we placed the flasks in an ultrasonic bath (Selecta) for $10 \mathrm{~min}$, and $100 \mu \mathrm{l}$ of six serial dilutions $(1,1 / 2,1 / 10,1 / 40,1 / 200$, and 1/400) of each sample were separately plated on five media in petri dishes at $23 \pm$ $2{ }^{\circ} \mathrm{C}$ under fluorescent lights (12-h photoperiod, $350 \mu \mathrm{mol} \mathrm{m} \mathrm{m}^{-2} \mathrm{~s}^{-1}$ ). For each sample (fallen and aerial leaves) and dilution, there were two dishes containing each of the following media: WA, WA acidified with lactic acid $(2.5 \mathrm{ml}$ of a $25 \%$ [vol/vol] per liter of medium; AWA), potato dextrose agar (PDA), PDA acidified with lactic acid (APDA), and malt extract agar (MEA) (11). To obtain pure cultures, we transferred hyphal tips from the colonies of the fungi to dishes with fresh APDA that were incubated as described above until colonies were large enough to be examined. All isolates were characterized morphologically according to color, growth, and presence or absence of conidiomata after 14 days of growth (Table 1). 
The length and width of 20 conidia per isolate were also measured, and their color, shape, and septation were recorded. The genera of fungi were determined according to published descriptions $(2,8)$. In all cases, fungi were identified to the genus level, except for Coleophoma oleae. Therefore, there may be several species belonging to a single genus. In total, 120 dishes (two samples [fallen or aerial leaves], six dilutions, five culture media, and two dishes) were used, and the experiment was conducted in November 1995, August and October 1996, and January 1997. Finally, the number of genera and the frequency at which each genus was isolated were determined for aerial and fallen leaves.

Spore dispersal. Volumetric spore traps. Conidia of S. oleagina were sampled with a 7-day volumetric spore trap (Burkard Manufacturing Co. Ltd.) working with alternating current. Air was sampled at approximately 10 liters/min. The trap was placed $1 \mathrm{~m}$ above ground level in the center of four olive trees in a 7-by-7-m square in the experimental orchard. The trap was operated from February to April 1994, and the sticky tape that collected the spores was replaced weekly. In the laboratory, the tape was cut into daily segments $(48 \mathrm{~mm})$, which were examined every other day. The entire area of each daily segment was scanned with a microscope at $\times 400$ magnification, and the $S$. oleagina conidia were counted and expressed as the number per week.

Glass microscope slide spore traps. Glass microscope slides provided a rapid and easy way to quantify $S$. oleagina conidia in olive orchards. Glass microscope slides ( 26 by $75 \mathrm{~mm}$ ) coated on both sides with a thin double-sided adhesive tape ( 24 by $50 \mathrm{~mm}$; Tanglefoot Company) were placed on wooden stakes at $1 \mathrm{~m}$ above the ground in the experimental orchard. Eight microscope slides (four in horizontal and four in vertical position) were placed on each stake. Eight stakes were placed from each distance (0 [under the olive canopy], 4,10 , or $40 \mathrm{~m}$ ) in the same direction from a highly affected tree located in the edge of the orchard. After 1 week, 129.6 $\mathrm{mm}^{2}$ of the area of each slide (12 stripes by $24 \mathrm{~mm}$ [tape width] by $0.45 \mathrm{~mm}$ (diameter of a visual field of $\times 40$ microscope objective]) was scanned at $\times 400$ magnification and the $S$. oleagina conidia were counted. The study was carried out five times from November 1996 to April 1997. The inoculum source, a heavily infected olive tree, was similar among years and months.

Data analysis. Data were analyzed using Statistix 9 (Analytical Software). The descriptive statistics for the variables (mean, standard deviation, variance, standard error of the mean, minimum, and maximum) were calculated using the summary statistics of the software. Pearson's correlation was used to evaluate the relationships between the number of conidia per square centimeter of lesion and viability (percentage of conidia germination). Moreover, the number of viable conidia (number of conidia produced multiplied by their viability) and the number of cumulative viable conidia were determined and plotted over time. We assume that the spores produced in a week were removed each week by rainfall. Because the cumulative number of viable conidia over time approached a maximum level asymptotically, data were fitted using different models of saturation with clear biological meaning $(10,13) ; 22$ September (the equinox of autumn) was considered day zero. The best regression model was chosen based on Akaike's information criterion, the coefficient of determination $\left(R^{2}\right)$, and the normal distribution of errors and by examining graphs of the standardized residuals plotted against predicted values. To study the effect of season on the cumulative number of viable conidia per square centimeter of lesion produced over time, we linearized the selected models of each season and compared the regression lines based on their homogeneity of variances, slopes, and intercepts.

The effect of date on inoculum density (conidia per square centimeter of lesion) on the leaves that were placed on the soil surface was determined with analysis of variance. The inoculum density values were $\log$ transformed when it was necessary for homogeneity of variance. The means obtained at different evaluation times were compared using Tukey's honestly significant difference test at $P=0.05$. To study the frequency (percentage) of isolation of other fungal species from olive leaves placed on soil surface or olive canopy, we applied a Fisher's exact test for each fungal species at $P=0.05$.

The relationship between rainfall and density of trapped $S$. oleagina conidia was evaluated by linear regression using an equation forced through the origin. In the linear regression analyses, the following were determined: the significance of the regression, $R^{2}$, the $R^{2}$ adjusted for degrees of freedom $\left(R_{a}^{2}\right)$, and the pattern of residuals. Finally, the power law and different exponential models, which describe the influence of distance from the source of inoculum on density of trapped conidia, were tested $(4,5,10)$. The best model was selected as described above. All of the regression models used in this study were developed with an empirical approach; that is, the form of the model was determined by the data collected (10).

\section{Results}

Survival on aerial or fallen infected leaves. The pathogen did not produce new conidia on lesions in leaves placed on the soil surface. In about $5 \%$ of the samples that were placed on the soil surface, the pathogen developed a stroma with a pseudoparenchymal spherical tissue similar to immature pseudothecia of Venturia spp. or sclerotia; however, mature pseudothecia with asci and ascospores were never observed. Likewise, enlarged intercalary cells of hyphae similar to chlamydospores were observed on $10 \%$ of the leaves placed on the soil surface. Overall, leaves on the soil were rapidly colonized by saprophytic fungi during the wet periods. The most common of these fungi was $C$. oleae, followed by species of Alternaria, Aureobasidium, Cladosporium, Epicoccum, and Phoma.

The pathogen did not produce new conidia around the lesions (whitish spots) of aerial leaves collected in September 1995, after a summer that was characterized by high temperatures (up to $45^{\circ} \mathrm{C}$ ). However, the pathogen produced new conidia around the whitish spots in September 1997 after a mild summer.

In olive leaves that had overwintered on the soil surface and were collected at the end of winter in the main olive-growing areas of Andalusia, the pathogen was not easily detected. No conidia were observed in old scab lesions, and only some pseudothecialike structures and chlamydospores were observed. As in the experimental orchard, all leaves were colonized by saprophytic fungi, mainly $C$. oleae and unidentified species of Alternaria, Cladosporium, Epicoccum, Fusarium, Mucor, Phoma, Rhizopus, and Trichoderma.

Conidial density and viability on aerial and fallen infected leaves. Different patterns of conidial density of S. oleagina on aerial leaves were observed across seasons (Fig. 1). Three of the four seasons (1993-94, 1994-95, and 1996-97) were favorable for olive scab epidemics and one season (1995-96) was unfavorable. In 1993-94, the pathogen produced conidia from the end of October until the end of June, although conidial density was not quantified during this first season; germination of conidia was 45 to $80 \%$ in this season. In 1994-95, conidia were detected from the end of November to July (i.e., the period was 1 month shorter than in the previous season) and conidial germination was 2 to $73 \%$. During 1994-95, the pathogen produced $>1.5 \times 10^{5}$ conidia $\mathrm{cm}^{-2}$ of lesion during the winter, with a peak in December and another in February. From February to the end of March, density of S. oleagina conidia decreased markedly and remained low $\left(<5 \times 10^{4}\right.$ conidia $\mathrm{cm}^{-2}$ of lesion) until July. In the unfavorable season (1995-96), the pathogen produced only a few conidia $\left(<2 \times 10^{4}\right.$ conidia $\mathrm{cm}^{-2}$ of lesion) on infected leaves from May to mid-July, although most conidia ( $>60 \%$ ) germinated. In the 1996-97 season, conidial density was large $\left(>1.8 \times 10^{5}\right.$ conidia $\mathrm{cm}^{-2}$ of lesion) from October to December, decreased from December until April $\left(1.4 \times 10^{4}\right.$ conidia $\mathrm{cm}^{-2}$ of lesion), and remained low during the spring and summer. In most months of the last season, the percentage of conidial germination was $>40 \%$, with a marked decline in March and another in August. The pathogen did not produce conidia during the summer, with one exception that occurred in 1997, when a few conidia were detected during July and August (Fig. 1).

Overall, the number of viable conidia per unit area of lesion was greatest during November to December and decreased gradually 
from this time until April (Fig. 2A); from April to autumn, this value was zero or near zero. In all cases, the cumulative number of conidia per unit area of lesion through the season (Fig. 2B) was best described by a monomolecular model with the following equation:

$$
Y=a\left[1-e^{-b(t-c)}\right]
$$

in which $Y=$ the cumulative number of conidia, $a=$ maximum cumulative number of conidia or asymptote, $t=$ days after 22 September, and $b$ and $c$ represent unknown parameters. The above equation can be linearized as:

$\operatorname{Ln}(a-Y)=\operatorname{Ln} a+b c-b t$

The fitted and linearized models for the three seasons were $\operatorname{Ln}(a-Y)=16.702-0.034 t, \operatorname{Ln}(a-Y)=41.371-0.1384 t$, and $\operatorname{Ln}(a-Y)=15.600-0.0281 t$ in 1994-95, 1995-96, and 1996-97, respectively; in all three seasons, $P<0.002$ and $R^{2}$ and $R^{2} a>0.83$. There was a significant $(P=0.036)$ difference between the slopes ( $b=$ the rate of conidia increase) but there were no differences $(P$ $=0.585)$ between the elevations of the regression lines of favorable seasons (1994-95 and 1996-97) for the epidemics. In both seasons, the cumulative number of viable conidia approached a maximum at the end of March (Fig. 2B).

The pathogen did not produce conidia on infected leaves that were placed on the soil surface, although the preexisting conidia were detected on lesions of leaves for up to 12 weeks. The leaves were rapidly colonized by saprophytic fungi, mainly species of Alternaria, Aureobasidium, and Cladosporium. Overall, the number of conidia and their viability decreased after the leaves were placed on the soil surface (Fig. 3). Nevertheless, there were important differences among trials (evaluation periods) because the colonization and degradation of leaf tissue by saprophytic microorganisms was faster when the weather was humid rather than dry. Thus, the cumulative rainfall during the trials of March 1995, Sep- tember 1996, and April 1997 was 29.4, 404.0, and $158.4 \mathrm{~mm}$, respectively. In the first trial, conidium density and germination did not significantly change during the first month $(P>0.05)$ but then decreased markedly (Fig. 3A). In the second trial, the density of $S$. oleagina conidia in the leaf lesions decreased during the first month and remained low during the second month (Fig. 3B). The density of conidia in lesions of the leaves at the beginning of the third trial was around $1 / 10$ of the density in the previous trials; however, a low density of conidia remained on the leaves for another 28 days. Although conidial density was relatively constant over time, it did differ $(P=0.012)$ among evaluation times. During the first month of the third trial, the percentage of conidial germination was high $(>70 \%)$ and decreased in the following weeks (Fig. 3C). In all three trials, conidial density on lesions was correlated (Pearson test, $P<0.005$ ) with the percentage of conidial germination.

Fungal diversity on aerial or fallen infected leaves. Numerous fungal species of 10 common saprophytic genera were isolated from leaves of the tree canopy. In addition, several fungal species of six genera more were isolated from fallen leaves (Table 1). Colonies of $S$. oleagina were not obtained from both kinds of leaves. Because there were no differences in the percentage of fungal isolations among evaluation times (November 1995, August and October 1996, and January 1997), results were combined in Table 1. Among the aerial leaves, Phoma was the genus most frequently isolated, followed by Alternaria. Both genera were also common on fallen leaves. The genera Cladosporium and Rhizopus were also isolated from aerial and fallen leaves but they were more frequently isolated from fallen leaves. Ascochyta, Aureobasidium, Coniothyrium, Fusarium, Diplodia, and Ulocladium genera were isolated only from aerial leaves. Conversely, the genera Mucor and Trichoderma were isolated only from fallen leaves (Table 1). Pycnidia and conidia of the fungus $C$. oleae were observed in most of the fallen leaves and on some aerial leaves that showed necrotic
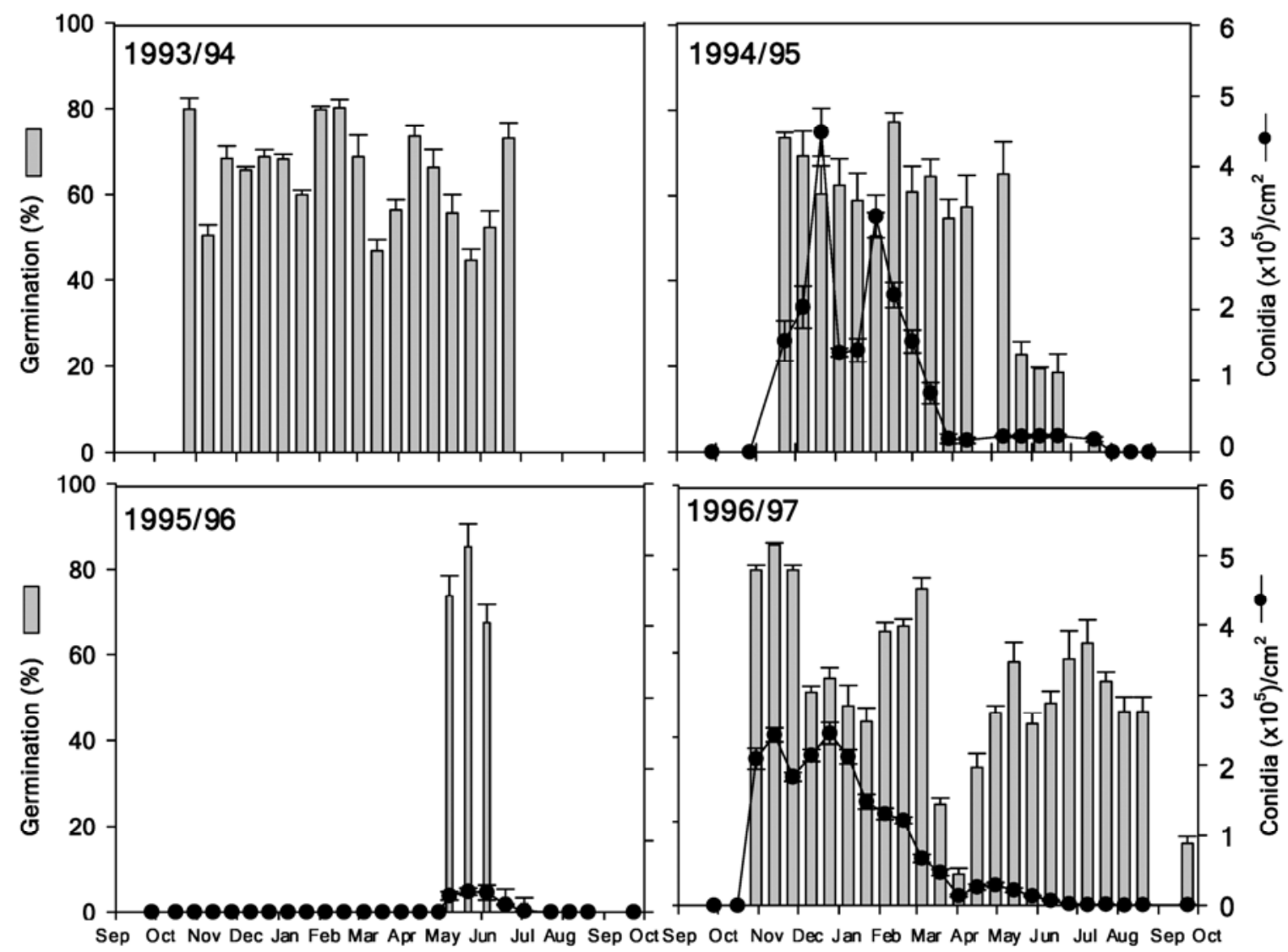

Fig. 1. Germination and density of Spilocaea oleagina conidia produced on nonfallen, infected olive leaves. Infected leaves collected from the tree canopy in the Andalusia region of southern Spain during four seasons were incubated in the laboratory. During the season 1993-94, only conidial germination was measured. Values for conidial density are the means of 120 replicate leaves, and values for conidial germination are the means of 400 conidia. Bars represent the standard error of the mean. 
areas but $C$. oleae was not isolated from the sampled leaves. No fungi isolated during this study produced sexual structures on olive leaves. A few bacterial colonies were obtained on WA and PDA media but they were not identified in this study.

Spore dispersal. Volumetric spore traps. Because of their characteristic morphology (shape, size, and color), S. oleagina conidia were easily identified on the spore sample tape (and also on leaves and microscope slides). However, from February to July 1994, only 47 conidia of $S$. oleagina were trapped on the continuously operated spore sampler tape, in spite of the presence of abundant visible inoculum in the orchard (data not shown). Of the 47 conidia on the spore tape, 42 were attached to the peltate trichomes of olive leaves.

Glass microscope slide spore traps. The number of S. oleagina conidia trapped on microscope slides depended greatly on rainfall and distance from the inoculum source (Table 2). There was a positive relationship between the number of conidia trapped and rainfall when the slides were placed directly under the canopy (distance $=0 \mathrm{~m}$ ) and at distances of 4 and $10 \mathrm{~m}$ from the canopy of a highly infected tree (Table 2). The number of conidia trapped under the olive canopy was 1,130 to 5 conidia $/ \mathrm{cm}^{2}$ of slide during the period of highest rainfall $(114.0 \mathrm{~mm}, 13$ to 20 January 1997) and the driest period (0 mm, 20 to 27 March 1997), respectively (Table 2). However, $21 \mathrm{~h}$ of leaf wetness was measured in the olive canopy during those dry periods due to the dew. The number of $S$. oleagina conidia trapped was highest under the olive canopy and decreased exponentially with distance from the canopy. Thus, the slides that were located at $40 \mathrm{~m}$ trapped only a small number of conidia and only during the two periods with the highest rainfall $(>60 \mathrm{~mm})$. Several linear and nonlinear models were evaluated to
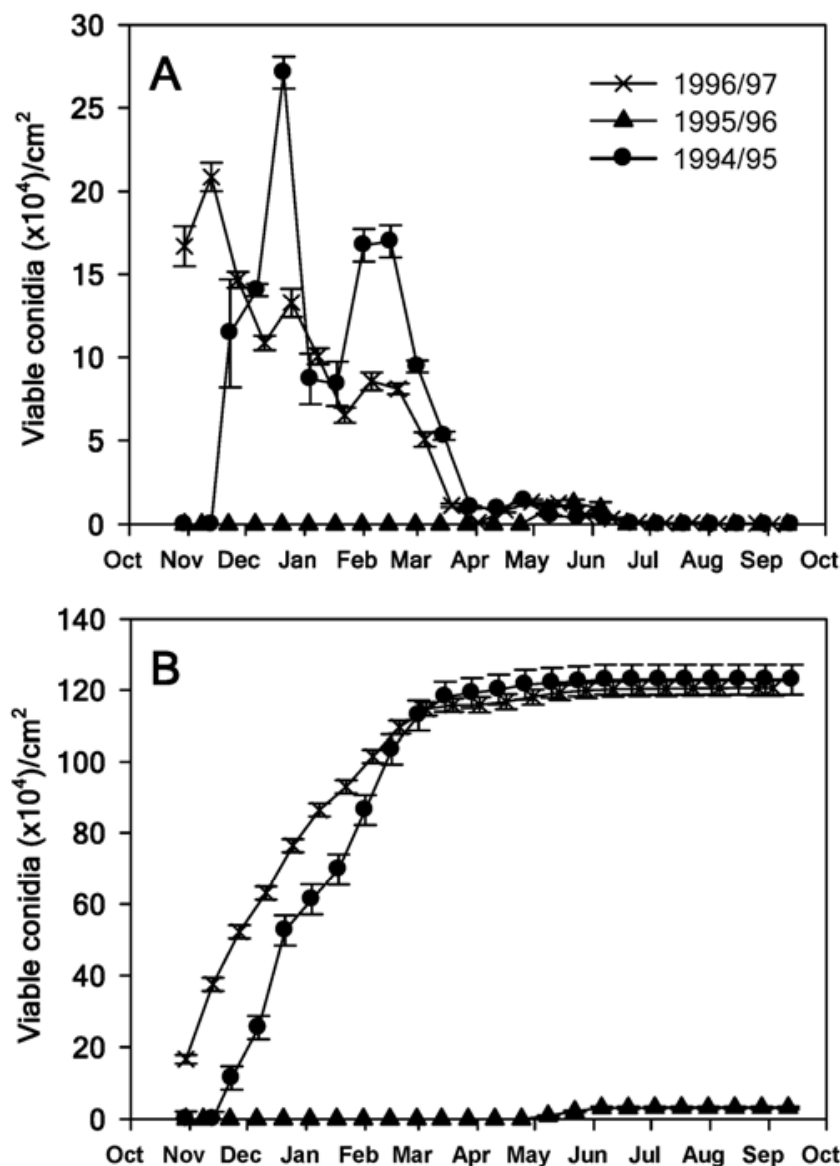

Fig. 2. Density of viable conidia of Spilocaea oleagina produced on infected olive leaves. Infected leaves showing scab lesions were collected from the tree canopy in Andalusia region of southern Spain through three seasons (1994-95, 1995-96, and 1996-97). A, Density on each sampling date. B, Cumulative density. Values are the means of 120 leaves, and bars represent the standard error of the mean. describe the effect of distance on dispersal and best and simplest was the exponential model:

$Y=a e^{-b S}$

in which $Y=$ density of trapped conidia (conidia per square centimeter), $S=$ distance (m) from the source of inoculum, $a$ represents the average density of inoculum under the olive canopy (at $S=0$ ), and $b$ is the unknown parameter that represents the slope of the dispersal gradient $\left(\mathrm{m}^{-1}\right)$. The equation adjusted for the observed data was $Y=396.52 e^{-0.4335 S}$. The equation's $R^{2}$ was 0.9890 , and standardized residuals were randomly distributed over predicted $Y$. The relationship between $Y$ and $S$ is described in Figure 4.
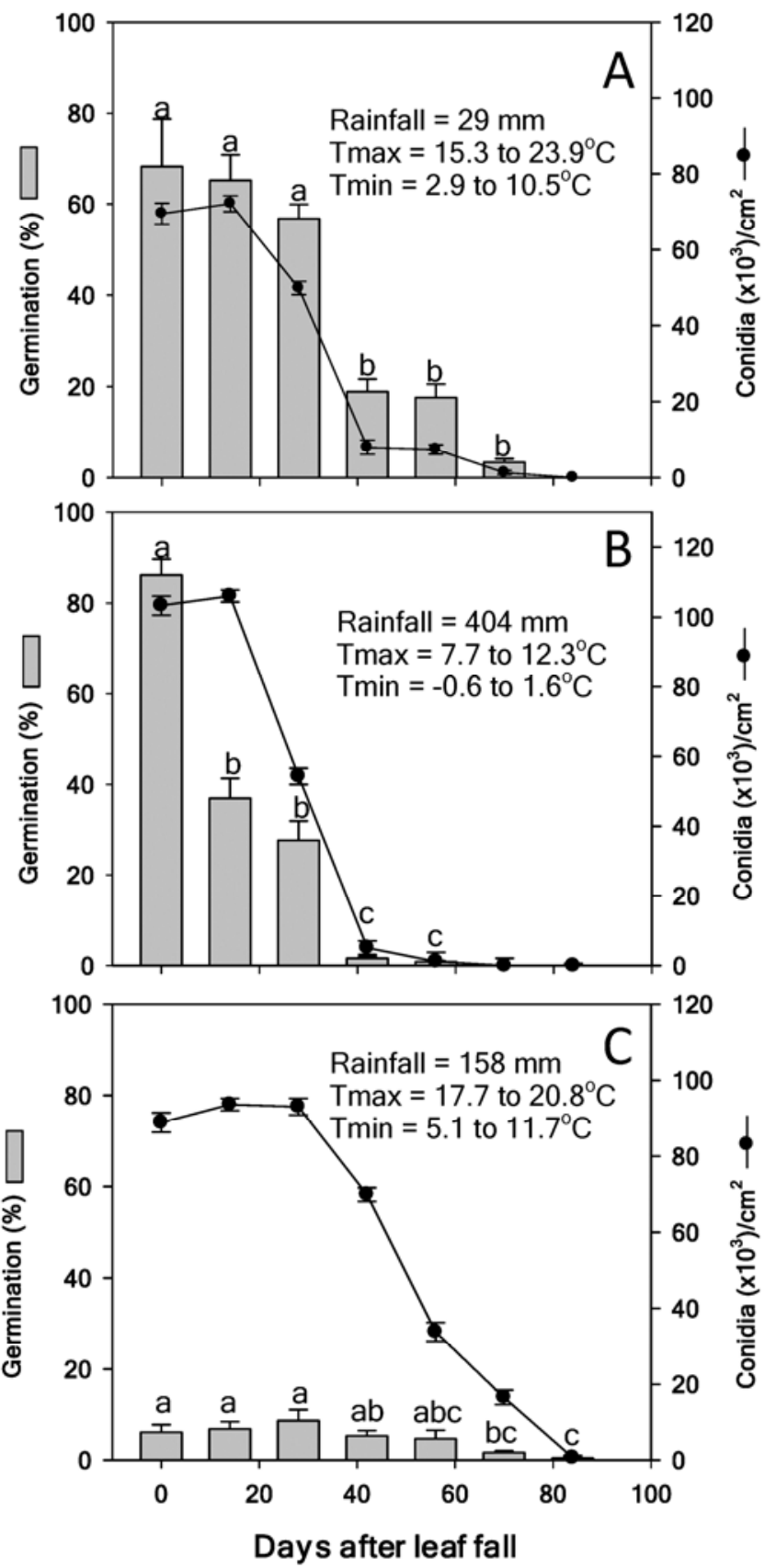

Fig. 3. Germination and density of Spilocaea oleagina conidia produced on infected olive leaves that were placed on the soil surface beneath the olive canopy in the Andalusia region of southern Spain during three growing seasons: A, 1994-95; B, 1995-96; and C, 1996-97. For each period, Tmax = maximum temperature range $\left({ }^{\circ} \mathrm{C}\right)$, Tmin $=$ minimum temperature range $\left({ }^{\circ} \mathrm{C}\right)$, and Rainfall $=$ cumulate rainfall (mm). Values for conidial density are the mean of 120 leaves, and values for germination are the mean of 400 conidia. Bars represent the standard error of the mean. Values for germination with the same letter are not significantly different according to Fisher's protected honestly significant difference test at $P=0.05$. 


\section{Discussion}

In this study, the most important inoculum source of $S$. oleagina was determined to be the infected leaves that remain in the olive canopy because we were unable to detect any new conidia on the fallen leaves. Our data also indicated that high temperature during the summer limits the viability of $S$. oleagina conidia on the aerial leaves. Infected leaves of cultivated olive trees and wild olive trees (O. europaea subsp. europaea var. sylvestris) are considered the only inoculum sources because $S$. oleagina is an obligate parasite and is specific to these hosts (26). Other authors have suggested that infected fallen leaves are an important inoculum source but they did not provide any epidemiological evidence to support this claim $(17,20,46)$. Although our results indicate that fallen leaves are not an inoculum source, we cannot exclude the possibility that they might function as an inoculum source under different weather conditions, with different populations of the pathogen, or in the presence of different saprophytic microorganisms.

Olive leaves that fall to the ground are usually decomposed quickly by saprophytic fungi and bacteria and also by soil fauna $(19,40,41)$. Thus, Miller (25) indicated that conidial production by $S$. oleagina on fallen leaves is markedly influenced by the saprophytic fungi in the soil. In our study, species of Phoma and $C$. oleae were the most abundant fungi on aerial and fallen leaves, respectively. According to Hudson (19), species of both genera are common on senescent leaves as saprophytes or secondary contaminants. Alternaria spp. were also frequently isolated from aerial and fallen leaves. Several species of Alternaria are mostly saprophytic, although Alternaria alternata has been described as a pathogen of olive fruit (27). In our study, we pointed out the most common genera of saprophytic fungi from olive leaves but further studies are needed for their specific identification and their potential use as biological control agents (35). Moreover, we observed, although it was not evaluated, that the decomposition of leaf tissue was faster during the wet than the dry periods, which is consistent with previous observations of olive leaves (19) and with the very large body of literature on leaf litter decomposition (7).

Sexual fruiting bodies of $S$. oleagina were not observed in this study or found in previous research done in California (25), Italy (15), or Morocco (17). However, in the current study, the pathogen did develop a pseudoparenchymal spherical tissue similar to immature pseudothecia of Venturia spp. Likewise, D'Oliveria and D'Oliveria (12) observed immature pseudothecia of S. eryobotryae on loquat leaves but were unable to confirm the occurrence of sexual reproduction on that host. Because $S$. oleagina does not develop pseudothecia, we think that its ability to survive in fallen leaves is limited. Pathogens similar to S. oleagina, such as species of Venturia (anamorphs: Cladosporium, Fusicladium, and Spilocaea), overwinter predominantly as pseudothecia that develop in leaves after their abscission $(23,39)$. Thus, pseudothecia are found more frequently in Venturiaceae species that are pathogenic on deciduous tree species such as apple (Malus), ash (Fraxinus), birch (Betula), cherry (Prunus), nectarine (Prunus), European and Asian pear (Pyrus), and peach (Prunus) $(23,38,39)$ than in Venturiaceae species that affect evergreen trees, including firethorn (Pyracantha), loquat (Eriobotrya), and olive $(15,21,33,37)$.

Several authors have described two peaks of conidial production by $S$. oleagina (one in November to December and another in March to April) in Italy (32), Morocco (14), and Turkey (6). Under our conditions, levels of viable inoculum were highest from midNovember to mid-December, although we evaluated the density of conidia on lesions and not the total production of conidia. In addition to conidial density and viability, the available inoculum also depends on disease incidence and severity, which reach the highest values in February-March in Andalusia $(43,45)$. The elevated temperatures during the spring in Córdoba Province and the susceptibility of 'Picual' olive could help explain the differences between our results and those of the other authors. In our study, the highest conidial density occurred several weeks before bud break. At this time, however, the olive tree has only mature leaves, which have ontogenic resistance to infection by the pathogen $(31,44)$. The main infection period in the Andalusia Region is from March to April due to the presence of developing leaves of olive, S. oleagina

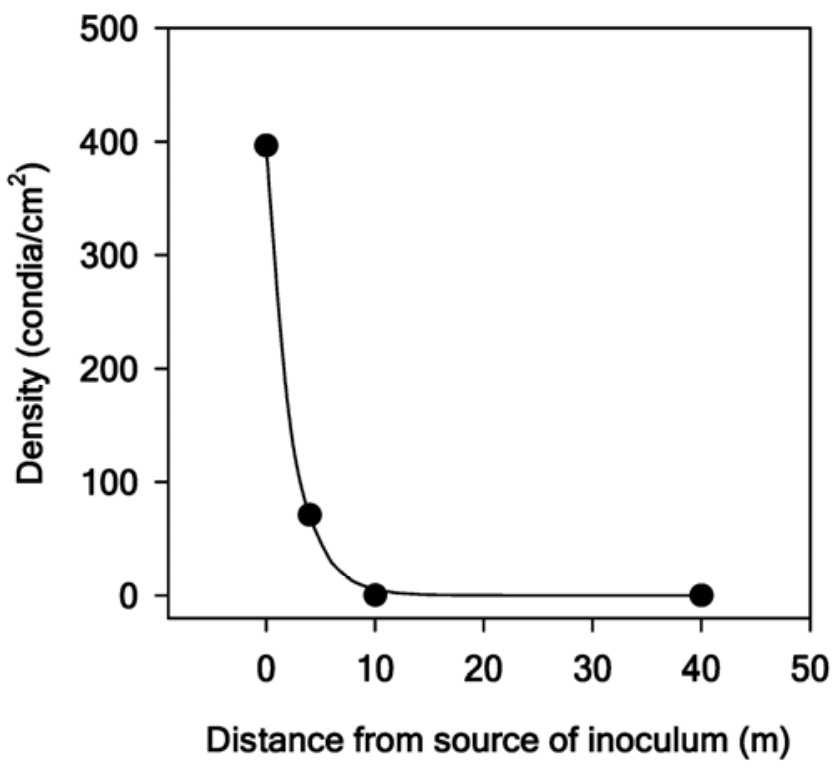

Fig. 4. Relationship between the number of Spilocaea oleagina conidia trapped per square centimeter of microscope slide and distance from the inoculum source. The line represents the exponential model $\left(Y=396.52 e^{-0.4335 S}\right)$ relating density of trapped conidia $\left[Y\left(\right.\right.$ conidia $\left.\left./ \mathrm{cm}^{2}\right)\right]$ to distance $(\mathrm{S})$ from the inoculum source. Values are the observed means of 320 microscope slides. The equation fit the observed data with $R^{2}=0.9890$

Table 2. Relationship between density of trapped Spilocaea oleagina conidia on microscope slides and distance (m) from an olive tree with heavily infected leaves $^{\mathrm{a}}$

\begin{tabular}{|c|c|c|c|c|c|}
\hline \multirow[b]{2}{*}{ Time period } & \multirow[b]{2}{*}{ Rainfall $(\mathbf{m m})^{\mathrm{c}}$} & \multicolumn{4}{|c|}{ Number of conidia trapped (per $\mathrm{cm}^{2}$ of slide) $)^{\mathrm{b}}$} \\
\hline & & $\mathbf{0} \mathbf{m}$ & $4 \mathrm{~m}$ & $10 \mathrm{~m}$ & $40 \mathrm{~m}$ \\
\hline 13-20 January 1997 & 114.0 & $1,129.80$ & 24.59 & 0.41 & 0.09 \\
\hline 06-13 December 1996 & 68.0 & 549.00 & 8.62 & 0.29 & 0.05 \\
\hline 17-24 April 1997 & 17.6 & 154.03 & 2.22 & 0.05 & 0.00 \\
\hline 15-22 November 1996 & 4.0 & 144.68 & 0.06 & 0.00 & 0.00 \\
\hline 20-27 March 1997 & 0.0 & 5.11 & 0.00 & 0.00 & 0.00 \\
\hline Linear regression $^{\mathrm{d}}$ & $\ldots$ & $Y=9.440 X$ & $Y=0.191 X$ & $Y=0.004 X$ & $\ldots$ \\
\hline$R^{2}$ & $\ldots$ & 0.9858 & 0.9579 & 0.9921 & $\ldots$ \\
\hline$P$ & $\ldots$ & $<0.0001$ & $<0.0001$ & $<0.0001$ & $\ldots$ \\
\hline
\end{tabular}

${ }^{a}$ Level of infection was similar among years and months with almost $50 \%$ of leaves showing sporulate lesions.

${ }^{\mathrm{b}}$ Conidial traps were placed under the olive canopy $(0 \mathrm{~m})$ or at 4,10 , or $40 \mathrm{~m}$ from the canopy.

${ }^{\mathrm{c}}$ Cumulative rainfall during 7 days.

${ }^{\mathrm{d}}$ Linear regression equation for density of trapped conidia $(Y)$ versus rainfall $(X)$; the coefficient of determination $\left(R^{2}\right)$ and significance $(P)$ of the regressions are also indicated. 
conidia, and rainfall, although infections can also occur during late spring and autumn (42). Even so, treatments with copper-based fungicides during the winter, before bud break, will be useful if there is a significant number of conidia in leaf lesions because copper-based fungicides reduce the viability of $S$. oleagina conidia $(34,35)$. Such an approach has been validated experimentally $(34,35,43)$ and is now a standard recommendation for producers (41). It is interesting to remark that treatments with copper-based fungicides are essential during the autumn for control of olive anthracnose, caused by Colletotrichum spp., in orchards where susceptible cultivars such as 'Galega vulgar', 'Hojiblanca', or Picudo are grown $(28,29)$.

In addition to being affected by leaf maturity and inoculum density, risk of leaf infection by $S$. oleagina is also contingent on rainfall. Conidia, spread in splashing water, are deposited on the leaf surface and will then infect and cause symptoms if the temperature is favorable and leaf tissues are susceptible to infection $(40,46)$. Previous spore-trapping studies in olive orchards in Italy showed that $S$. oleagina conidia are mainly spread as airborne inoculum during periods of rainfall $(22,24)$. These studies have also demonstrated that a small number of conidia can also be spread by wind alone for at least $20 \mathrm{~m}$ from the inoculum source (22). Conidia can also be transported by the insect Ectopsocus briggsi (24). Because the number of conidia trapped close to the inoculum source $(<40$ $\mathrm{m})$ was linearly and positively related to the cumulative rainfall, our results strongly indicate that conidia of S. oleagina are watersplash dispersed and for only short distances. The number of dispersed conidia decreased exponentially with increasing distance from the inoculum source. A small number of $S$. oleagina conidia were trapped beneath the olive tree canopy during the dry period, suggesting that dew may enable a limited degree of vertical dissemination of conidia within the canopy of the olive tree. Using a volumetric spore trapping, we observed that some conidia were associated with the leaf trichomes. The peltate trichomes of olive leaves resemble umbrellas and might act like parachutes and thereby enhance conidia dispersal. This may explain how the disease spreads from one olive grove to another, given that wind and rain alone do not result in substantial dispersal for distances $>20 \mathrm{~m}$ (24).

The most widely used empirical models for describing the relationship between spore dispersal and distance from a source of inoculum are the power law model and simple exponential models (10). Fitt et al. (14) compared both models and concluded that they had limitations, although the exponential model can be more easily incorporated into models of disease development than the power law model because the boundary condition at the source is finite rather than infinite. The data for number of conidia trapped with increasing distance from an affected olive tree were better described by the exponential model than the power law model, which was in agreement with the results of a previous study (22). Overall, when pathogens are rain-splash dispersed, the exponential model may be a better fit than the power law model (10).

Although this study of S. oleagina has documented patterns of conidial production and dispersion and previous studies established the factors affecting infection of leaves $(31,44)$, a more detailed examination of the temporal progress of the disease is needed to identify cultivar and environmental factors that determine epidemic development. Such information should support the design of a disease forecasting system for the proper timing of fungicide treatments.

Results of this study are also applicable in managing the disease. Because it has been shown that the fallen leaves are not an important source of inoculum for the disease, traditional cultural practices used to remove fallen leaves appear unnecessary and should not be recommended. The dynamics of the inoculum on leaves observed in this study will also help to establish a better timing for fungicide treatments.

\section{Acknowledgments}

J. R. Viruega and J. Moral contributed equally to this article. This research was supported by projects AGF93-0342 and AGF96-1082 from the CICYT, the
Spanish Ministry of Education and Science (MEC), and project AGR-03635 from DGPA, Andalusia Regional Government. J. Moral is the holder a Juan de la Cierva Post-Doc grant from MEC. We thank F. Luque for her valuable technical assistance and C. M. Díez, D. Gramaje, B. Jaffe, and W. J. Kaiser for critical review of the manuscript.

\section{Literature Cited}

1. Andrés, F. De. 1991. Enfermedades y plagas del olivo. 2a ed. Riquelme y Vargas Ediciones, Jaén, Spain.

2. Arx, J. A. 1981. The Genera of Fungi Sporulating in Pure Culture. J. Kramer Verlag, Vaduz, Liechtenstein.

3. Assawah, M. W. 1967. Cycloconium leaf spot of olive in Egypt. Phytopathol. Mediterr. 6:144-148

4. Aylor, D. E. 1995. Vertical variation of aerial concentration of Venturia inaequalis ascospores in apple orchard. Phytopathology 85:175-181.

5. Aylor, D. E. 1999. Biophysical scaling and the passive dispersal of fungus spores: Relationship to integrated pest management strategies. Agric. For. Meteorol. 97:275-292.

6. Azeri, T. 1993. Research on olive leaf spot, olive knot and Verticillium wilt of olive in Turkey. EPPO Bull. 23:437-440.

7. Bardgett, R. D. 2005. The Biology of Soil: A Community and Ecosystem Approach. Oxford University Press, New York.

8. Barnett, H. L., and Hunter, B. B. 1998. Illustrated Genera of Imperfect Fungi, 4th ed. American Phytopathological Society, St. Paul, MN.

9. Barranco, D., Fernández-Escobar, R., and Rallo, L. 2010. Olive Growing. Junta de Andalucía/Mundi-Prensa/RIRDC/AOA, Pendle Hill, NSW, Australia.

10. Campbell, C. L., and Madden, L. V. 1990. Introduction to Plant Disease Epidemiology. John Wiley \& Sons, New York.

11. Dhingra, O. D., and Sinclair, J. B. 1995. Basic Plant Pathology Methods. CRC Press, Boca Raton, FL.

12. D'Oliveira, B., and D'Oliveira, M. 1946. Nota sôbre os corpos do tricoginio e do anteridio nas Venturia inaequalis, $V$. pirina, e $V$. eriobotryae. Agron. Lusit. 8:291-301

13. Duthie, J. A. 1997. Models of the response of foliar parasites to the combined effects of temperature and duration of wetness. Phytopathology 87:1088-1095

14. Fitt, B. D. L., Gregory, P. H., Todd, A. D., McCartney, H. A, and MacDonald, O. C. 1987. Spore dispersal and plant disease gradients: a comparison between two empirical models. J. Phytopathol. 118:227-242.

15. Graniti, A. 1993. Olive scab: A review. EPPO Bull. 23:377-384.

16. Graniti, A., and Laviola, C. 1981. Sguardo generale alle malattie parassitarie dell'olivo. Inf. Fitopatol. 31:77-92.

17. Guechi, A., and Girre, L. 1994. Sources of Cycloconium oleaginum (Cast.) conidia for infection of olive leaves and conditions determining leaf spot disease development in the region of Sétif, Algeria. Mycopathologia 125:163-171.

18. Holb, I. J., Heijne, B., Withagen, J. C. M., and Jeger, M. J. 2004. Dispersal of Venturia inaequalis ascospores and disease gradients from a defined inoculum source. J. Phytopathol. 152:639-646.

19. Hudson, H. J. 1971. The development of the saprophytic fungal flora as leaves senesce and fall. Pages 447-445 in: Ecology of Leaf Surface Microorganisms. T. F. Preece and C. H. Dickinson, eds. Academic Press, London.

20. Laviola, C. 1968. Aspetti biologici ed epifitologici di Spilocaea oleagina (Cast.) Hugh. in Italia. Ann. Fac. Agrar. Univ. Bari 22:345-360.

21. Le Cam, B., Parisi, L., and Arene, L. 2002. Evidence of two formae speciales in Venturia inaequalis, responsible for apple and Pyracantha scab. Phytopathology 92:314-320.

22. Lops, F., Frisullo, S., and Rossi, V. 1993. Studies on the spread of the olive scab pathogen, Spilocaea oleagina. EPPO Bull. 23:385-387.

23. MacHardy, W. E. 1996. Apple Scab: Biology, Epidemiology, and Management. American Phytopathological Society, St. Paul, MN.

24. Marzo, L. De, Frisullo, S., Lops, F., and Rossi, V. 1993. Possible dissemination of Spilocaea oleagina conidia by insects (Ectopsocus briggsi). EPPO Bull. 23:389-391.

25. Miller, H. N. 1949. Development of the leaf spot fungus in the olive leaf Phytopathology 39:403-410.

26. Moral, J., Ávila, A., López-Doncel, L. M., Alsalimiya, M., Oliveira, R., Gutiérrez, F., Navarro, N., Bouhmidi, K., Benali, A., Roca, L., and Trapero, A. 2005. Resistencia a los Repilos de distintas variedades de olivo. Vida Rural 208:34-40.

27. Moral, J., de la Rosa, R., León, L., Barranco, D., Michailides, T. J., and Trapero, A. 2008. High susceptibility of the olive cultivar FS-17 to Alternaria alternata in southern Spain. Plant Dis. 92:1252.

28. Moral, J., and Trapero, A. 2009. Assessing the susceptibility of olive cultivars to anthracnose caused by Colletotrichum acutatum. Plant Dis. 93:10281036.

29. Moral, J., and Trapero, A. 2012. Mummified fruit as a source of inoculum and infection dynamics of olive anthracnose caused by Colletotrichum acutatum. Phytopathology 102:982-989.

30. Obanor, F. O., Jaspers, M. V., Jones, E. E., and Walter, M. 2008. Greenhouse and field evaluation of fungicides for control of olive leaf spot in New Zealand. Crop Prot. 27:1335-1342. 
31. Obanor, F. O., Walter, M., Jones, E. E., and Jaspers, M. V. 2011. Effects of temperature, inoculum concentration, leaf age, and continuous and interrupted wetness on infection of olive plants by Spilocaea oleagina. Plant Pathol. 60:190-199.

32. Prota, U. 1958. Contributi alla patologia dell'olivo coltivato in Sardegna. Studi Sassar. Sez. 3(6):256-288.

33. Raabe, R. D., and Gardner, M. W., 1972. Scab of pyracantha, loquat, toyon, and kageneckia. Phytopathology 62:914-916.

34. Roca, L. F., Moral, J., Viruega, J. R., Ávila, A., Oliveira, R., and Trapero, A. 2007. Copper fungicides in the control of olive diseases. Olea 26:48-50.

35. Roca, L. F., Viruega, J. R., López-Doncel, L. M., Moral, J., and Trapero, A. 2010. Métodos culturales, químicos y biológicos de control del Repilo. Vida Rural 304:38-42.

36. Roubal, C., Regis, S., and Nicot, P. C. 2012. Field models for the prediction of leaf infection and latent period of Fusicladium oleagineum on olive based on rain, temperature and relative humidity. Plant Pathol. Online publication. doi:10.1111/j.1365-3059.2012.02666.x

37. Sánchez-Torres, P., Hinarejos, R., and Tuset, J. J. 2009. Characterization and pathogenicity of Fusicladium eriobotryae, the fungal pathogen responsible for loquat scab. Plant Dis. 93:1151-1157.

38. Schnabel, G., Schnabel, E. L., and Jones, A. L. 1999. Characterization of ribosomal DNA from Venturia inaequalis and its phylogenetic relationship to rDNA from other tree-fruit Venturia species. Phytopathology 89: 100-108.
39. Spotts, R. A., and Cervantes, L. A. 1994. Factors affecting maturation and release of ascospores of Venturia pirina in Oregon. Phytopathology 84:260 264.

40. Tenerini, I. 1964. Richerche sulla biologia de epidemiologia della Spilocaea oleaginea (Cast.) Hug., agente dell'occhio di pavone dell'olivo. Phytopathol. Mediterr. 3:63-70

41. Trapero, A., and Blanco, M. A. 2010. Diseases. Pages 521-578 in: Olive Growing. D. Barranco, R. Fernández-Escobar, and L. Rallo, eds. Junta de Andalucía/Mundi-Prensa/RIRDC/AOA, Pendle Hill, NSW, Australia.

42. Trapero, A., and Roca, L. F. 2004. Bases epidemiológicas para el control integrado de los "Repilos" del olivo. Phytoma España 164:130-137.

43. Viruega, J. R. 1999. Epidemiología del Repilo del olivo causado por Spilocaea oleagina Castagne (Hughes). Ph.D. thesis, Universidad de Córdoba, Córdoba, Spain.

44. Viruega, J. R., Roca, L. F., Moral, J., and Trapero, A. 2011. Factors affecting infection and disease development on olive leaves inoculated with Fusicladium oleagineum. Plant Dis. 95:1139-1146.

45. Viruega, J. R., and Trapero, A. 1999. Epidemiology of leaf spot of olive tree caused by Spilocaea oleagina in southern Spain. Acta Hortic. 474:531-534.

46. Wilson, E. E., and Miller, H. N. 1949. Olive leaf spot and its control with fungicides. Hilgardia 19:1-24.

47. Zhang, Y., Crous, P. W., Schoch, C., Bahkali, A. H., Guo, L. D., and Hyde, K. D. 2011. A molecular, morphological and ecological re-appraisal of Venturiales-a new order of Dothideomycetes. Fungal Divers. 51:249-277. 